\title{
Korrupsie en die toerusting van Christen-leiers
}

\section{Book Title:}

Corruption in South Africa's liberal democratic context: Equipping Christian leaders and communities for their role in countering corruption

\section{Book Cover:}

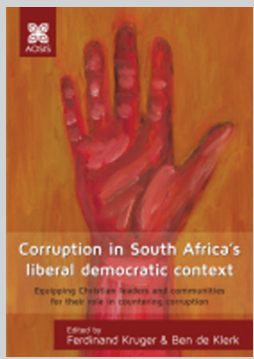

Editors:

Ferdinand Kruger Ben de Klerk

ISBN:

978-0-620-72526-2

Publisher:

AOSIS, 2016, R220.00*

*Book price at time of review

Review Title:

Korrupsie en die toerusting van Christen-leiers

Reviewer:

Ian A. Nell ${ }^{1}$

\section{Affiliation:}

${ }^{1}$ Department of Practical

Theology, Faculty of

Theology, University of

Stellenbosch, South Africa

How to cite this book review: Nell, I.A., 2017, 'Korrupsie en die toerusting van Christenleiers', In die Skriflig 51(1), a2319. https://doi.org/ 10.4102/ids.v51i1.2319

\section{Read online:}

Scan this QR code with your smart phone or mobile device to read online.

\section{'n Kort opsomming van die inhoud van die tema van die werk}

In hierdie publikasie poog die outeurs om prakties-teologiese riglyne vir Christen-leiers oor die teenwerking van korrupsie te ontwikkel. Hierdie riglyne is gevorm deur ' $n$ hermeneutiese interaksie tussen die bevindinge in die deskriptief-interpreterende en normatiewe afdelings, en deur die uiteindelike inkorporering van die bevindinge in die strategiese gedeelte van die studie.

Volgens die outeurs kan die impak van die diepgewortelde korrupsie in die Suid-Afrikaanse samelewing nie ontken word nie. Volgens hulle ontstaan wydverspreide korrupsie as gevolg van die misbruik van publieke bronne vir die verkryging van persoonlike finansiële voordele deur korrupte administrateurs wat wantroue in die huidige leierskap tot gevolg het.

Hulle beweer dat insig vir die oorsake van korrupsie en wat onder die oppervlak van die probleem daarvan lê nodig is. Praktiese teologie kan volgens hulle 'n bydrae lewer tot 'n indiepte ondersoek van die probleem. Om die probleem van korrupsie suksesvol te hanteer, beteken nie alleen die vervanging van korrupte leiers nie, maar ook die vernuwing van 'n antikorrupsie kultuur, van die publieke lewe en van individue. Christelike praktiese teologie lewer volgens die outeurs 'n unieke geleentheid om by die kern van korrupsie uit te kom en kan daarom 'n waardevolle bydrae maak tot die verduideliking en verstaan van sowel as die reaksie op die probleem deur onder andere die interaksie en interdissiplinêre dialoog aan ander menslike wetenskappe te meet.

Die basiese navorsingsvraag van die studie word soos volg deur die outeurs geformuleer:

What insight can be gained from a practical theological study regarding the deeply rooted causes and farreaching effects of corruption in a South African liberal democratic environment and what strategic elements are needed by Christian leaders to address this problem faithfully according to the normative indicators linked to their God-given calling?

Die outeurs gaan dan voort en voer hulle argument deur gebruik te maak van Rick Osmer se benadering tot praktiese teologie aan die hand van die volgende vier vrae: Wat gaan aan?; Hoekom is dit die geval?; Wat behoort te gebeur?; en Hoe verander ons dit? Hierdie vier vrae omskryf hulle deur van die volgende hoofde gebruik te maak:

- die aard van korrupsie;

- sommige van die hoofoorsake in 'n Afrika konteks;

- die bydraes wat Christelike tradisies kan maak om korrupsie te hanteer; en

- moontlike strategiese benaderings wat Christen-leiers kan oorweeg om die probleem te hanteer.

\section{'n Kort evaluering van die standaard en meriete van die werk}

Die outeurs lewer in die geheel werk van 'n goeie standaard en bevat die boek 'n magdom van interessante inligting - alles verbind aan die basiese navorsingsvraag wat, myns insiens, goed geformuleer is. Die taalgebruik is baie goed en die tegniese versorging van goeie gehalte.

Ek het veral hoofstukke 3, 4 en 5 baie waardevol gevind in die lig van interessante teorieë wat in verband met die onderliggende oorsake van korrupsie bespreek is en wat waardevolle lig op die onderwerp werp. Volgens my hanteer veral hoofstuk 5 van die belangrikste oorsake vir korrupsie vanuit ' $n$ etiese perspektief. 
In die lig hiervan lewer ek graag kommentaar oor enkele aspekte van die werk wat volgens my oordeel 'n voortgaande dialoog oor die onderwerp van korrupsie kan bevorder soos wat die outeurs ook op verskillende plekke in die boek voorstel.

Wat die metodologie as deel van die empiriese navorsing betref, vind ek dit ongelukkig problematies dat daar net van vier respondente gebruik gemaak is. Indien die outeurs ernstig daaroor is dat hulle sommige van die hoofoorsake van korrupsie in die Afrika-konteks wil ondersoek, sou 'n mens verwag dat hulle ten minste tussen 15 en 20 onderhoude gevoer het wat normaalweg die norm vir kwalitatiewe empiriese navorsing in die vorm van semi-gestruktureerde onderhoude is. Wat verder problematies is, is dat ' $n$ mens geen aanduiding vind van wie die respondente is nie. In hierdie tipe navorsing is dit gebruiklik om ten minste net die basiese inligting te verskaf rondom die geslag en ouderdom van die respondente.

Gesien in die lig van die hoogs kontroversiële aard van die navorsingsonderwerp, sou ek graag ook die volgende wou sien: eerstens, 'n idee van die twee Christelike leiers se betrokke denominasionele agtergronde; tweedens, van watter politieke party die politieke leier is; en derdens, watter sektor in die besigheidwêreld word deur die betrokke sakeman verteenwoordig? Of die Christelike leiers wat ondervra is deel van die Protestantse tradisie of van die onafhanklike kerke in Afrika (soos wat die outeurs self later in die boek aandui - vgl. bl. 57-60), sal 'n reuse verskil maak. Dit is duidelik dat hierdie twee agtergronde verskillende benaderings tot korrupsie sal hê. Dieselfde geld van die politieke leier (watter party) en besigheidsleier (watter sektor en watter ekonomiese model) hulle ondersteun?

Die rede waarom laasgenoemde opmerkings oor die empiriese deel van die studie belangrik is, hou verband met die feit dat die outeurs doelbewus die hele argument, wat hulle die 'konsepsuele raamwerk' noem, op grond van hierdie empiriese resultate bou. In hulle eie woorde: 'The conceptual framework, gleaned from the empirical data, functions for our practical theological reflection on corruption in the consecutive chapters.'

In die geheel dink ek egter dit is 'n goeie publikasie wat 'n baie relevante onderwerp in die Suid-Afrikaanse konteks benader. Dit lewer ' $n$ definitiewe bydrae tot die diskoers oor korrupsie. 